UDK 37.013.73

Pregledni rad Primljeno: 22.4.2019.

Revidirana verzija: 6.7.2019.

Odobreno za štampu: 8.7.2019.

DOI: https://doi.org/10.46630/gped.1.2019.07

\title{
ХУМАНИСТИЧКО-ВАСПИТНИ КОНЦЕПТ ЧОВЕКА: О (НЕ)МОГУЋЕМ КОМПЛЕМЕНТАРНОМ ОДНОСУ ЈЕЛИНСКЕ И САВРЕМЕНЕ ФИЛОСОФИЈЕ ВАСПИТАЫА
}

\author{
Милан Миљковић ${ }^{1}$ \\ Универзитет у Нишу, Филозофски факултет, Департман за педагогију \\ (студент ДАС)
}

\begin{abstract}
Ancmpaкm: Неоспорна је чињеница да јелинска философска мисао има како по обиму тако и по дубини универзалне и оригиналне продукте људске спознаје на свим истраживачким пољима појавног света у феноменолошком смислу. У контексту ове студије теоријски је селективно представљена јелинска философска мисао у духу паидеје ( $\pi \alpha 1 \delta \varepsilon i ́ \alpha)$, као и посмодернистичка хуманистичка мисао у сегменту философије васпитања. Као премисно тежиште истраживачког проблема у раду је анализиран однос компаративних модуларитета јелинско-nоcmмодрнистичке васпитне философије, те (не)могућност сагледавања њиховог комплементарног односа у сегменту интегрисаности јединственог теоријског

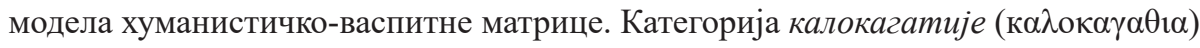
као јединствен и универзални филозофско-педагошки продукт јелинске културе разматра се као централни сегмент предметне структуре истраживачког поља. Истраживачки циљ студије усмерен је ка аналитичком испитивању могућности

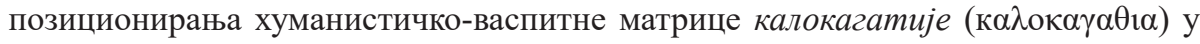
оквирима компаративних модуларитета јелинско-постмодрнистичке васпитне философије. У раду су размотрене основне теоријске поставке калокагатије као израза хуманистичко-васпитне топике јелинског духа, у оквиру кога је посебно дат осврт на Платонова схватања у сегменту култивисања и оплемењивања људске природе. Анализирана су различита теоријска становишта постмодернистичко-хуманистичке оријентације у сегменту хијерархијске интеграције основних категоријалних поставки од значаја за васпитни идеал калокагатије. Резултати компаративне анализе показују да базично полазиште хуманистич-

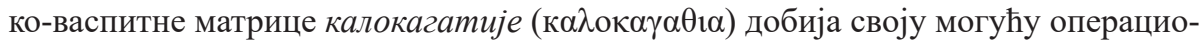
налну конотацију посредника између јелинске и постмодернистичке васпитне философије.
\end{abstract}

Кључне речи: васпитање, васпитна философија, калокагатија, хуманистичка матрица.

\footnotetext{
1'kalokagatija@gmail.com
} 


\section{Увод}

Хуманистичко-васпитни концепт човека у својој историјско-духовној генези развоја доживљава различите метаморфозне преображаје. У културолошко-цивилизацијском сегменту људске егзистенције темпорални континуум хуманистичке парадигме може се пратити као екстериоризована форма одређеног духа времена која per se успоставља образац како универзалистичких тако и особених хуманих вредности. Такав образац аксиолошког прерогатива али и акциденцијалног хабитуса људског чина (actus humanus) као таквог, најизраженије сврсисходно и целисходно оваплоћење доживљава у филозофској мисли и учењу старих јелина. Хуманистичка карактерна модуларност јелинског духа кроз митос идеалиогизира трагичност, смртност, беспомоћност, фаталност као егзистенцијалне и непомирљиве категоријалне нужности човекове судбине у односу на божански етос. Јелински дух у том смислу синонимизује божанску атрибутивну карактерологију у односу на човечанску у многим сегментима, примера ради, за старе јелине богови се рађају као и људи, на тај начин јелински ум апсорбује еквивалентност односа божанског и човечанског. Таква митолошка претензија да своје сопство приближи превалентном и бесмртном свету богова код старих јелина изнедриће богату лепезу опуса филозофских учења у коме аксиолошку предоминацију у односу на остале егзистенцијалне категорије има категорија arete (врлина). На базичном стожеру врлинског у коме идеализован човек остаје апокалиптично оруђе у рукама божанских провенијенција, рађа се идеја о савршено обликовном и хармонизованом човеку античке епохе - паидеја ( $\pi \alpha \iota \delta \varepsilon\{\alpha)$. Као тежња ка матријализацији духовног и практичног начина живљења, чувена јелинска паидеја образује уневерзални

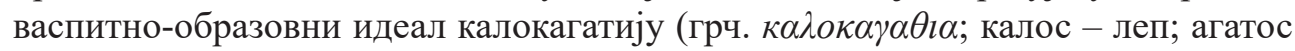
- добар), односно идеални модел обликовања грађанина старохеленског полиса ка коме је требало тежити како у онтолошко-етичком тако и аксиолошком димензионирању индивидуума, односно личности. Тако, у примарном фокусу микрокозмичке перспективе људског бића, хуманистичка основа васпитног

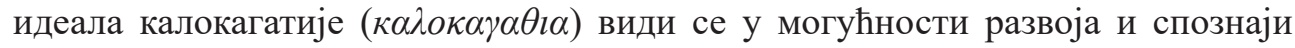
индивидуалних сопствених потенцијала сваког појединачног индивидуума, односно практично-синергијском односу и делању на релацији - конкретан појединаи - појавни свет реалности (друштво, природа, свет, космос...).

У испитивачко-теоријском фокусу студије с једне стране наглашава се апоријски карактер хуманистичко-васпитног модела човека као фундаментално-теоријски утемељено и базично постављено подручје у периоду античко-хеленске културе. Док с друге стране, као важна теоријско-истраживачка премиса види се аргумент који у темпоралној периодици постмодернистичког васпитног praxisa претпоставља нејединственост консензуса по питању утемељености хуманистичко-васпитног модела човека у философско-педагошком дискурсу XXI века. 


\section{1. Калокагатија као израз хуманистичко-васпитне топике јелинског духа}

Чувај калокагатију верније но заклетву

Солон

У јелинско-хуманистичком моделирању априористичке философсковаспитне топике, позиционирање појединаца као носиоца микрокозмичког етосног флуида интендиран је фантастичним спојем рационалистичко-материјалистичког елемента са мистично-трансцендеталним. Јелински дух као такав у испитивачком мултидимензионуму појавног света феномена рефлексира основу ејдетске стварности као аутентичност приступа јединствености човекове егзистенцијалне бити (Đurić, 1976). Тако средиште јелинско-духовног хабитуса егзистенцијално орбитира у и око хуманистичке концептуалне поставке сасвим специфичне и особене гносеолошко-епистемолошке природе. Генерична природност кроз коју је структурално изражен хуманистички модел човека исказан је и есенцијално садржан у апоријској сентенци antropos metron panton crematon: „човек је мера свих ствари, оних које јесу да јесу, а оних које нису да нису”. Поменута апорија тако изображава универзалну јединственост приступа хеленског духа сегментима појавног света ствари од круцијалног значаја за позиционирање и димензионирање хуманистичког концепта и модела човека. У низу разноврсности апоријских сентенци хуманистичког карактера, од којих је поменута само једна можда најпознатија софистичка, јелинска култура својом богатом и разноврсном философском топиком може се сматрати експлицитним представником хуманистичко-васпитне човекове бити.

Јелинска култура својим динамичко-експанзивним истраживачким духом на свим пољима духовно-инетлектуалног стваралаштва оставља импонзантне и задивљујуће продукте људске спознаје (Guthrie, 1962). Посматрано конкретније, из перспективе савременог друштвено-хуманистичког дискурса фасцинира чињеница да конципираност структурума философских система старих јелина у зависности од временске епохе у коме су се образовали и развијали представљају непревазиђене конструкционо-мислене обрасце. По питању своје аутентичности и оригиналности јелинска философија представља суштински важан конституент европске интелектуалне мисли чији се развој независно од старојелинског интелектуалног корпуса тешко може разумети и поимати (Zeller, 2014). Старојелински дух који у својој мултидимензионалној егзистенцијалној форми највљује почетак златног доба ( $\left.\alpha \alpha \_\varepsilon i ́ \alpha\right)$ хеленскоатинске културе постулира се у периоду од шестог века пре нове ере све до кулминације друштвено-делатног рада софиста и Сократа. Посматрано кроз контекст хуманистичке перцепције, философска мисао у том периоду достиже пуно хуманоидно обележје праћено епистемолошко-гносеолошком зрелошћу у погледу спознаје и сазнања хумане природности људског бића, те његовог положаја и делатне праксе у макрокозмичкој перспективи. Оправданост такве 
позиције у погледу хуманистичког структурума nаидеје налазимо у чињеници да јелински дух превазилажењем партикуларности у погледу његовог милитарног карактера, успева да развије и структуруише хомоцентричну свест о себи и својој универзалној вредности, чиме настоји да освоји остатак архаично-познатог света (Collingwood, 1994). Мислиоци попут Питагоре, Протагоре, Сократа, Платона, Аристотела развијају универзални модел техне ( $\tau \dot{\varepsilon} \chi v \eta)$ односно јелинску уметност начина живљења у најширем смислу речи, која у синергичној рефлексији друштвених реалности постулира испитивње људске природе на узвишенији степен (non grado) схватања и разумевања. Ипак, сам период духовно-интелектуалног оформљења јелинске паидеје праћен је синкретичким нејединством философско-концептуалног утемељења који у складу са философским пропорцијама одређених мислилаца даје најразноврсније одговоре у односу на положај и природу људске бити. Основне смернице испитивања хуманистичких детерминанти у том смислу могу се сагледати као основе хуманистичко-васпитног модела човека при чему и постмодернистичка педагошка мисао има потребу за одговором о природи процеса васпитања као о бићу у настајању (Mills, 2002). Идеолошко-хомоцентрична структура паидеје својом конзеквентном рефлексивном мултидимензионалшћу у делатно-друштвеној пракси полиса постулира, односно користећи се сократовском терминологијом „мајеутише“ (порађа) васпитно-образовни модуларитет - калокагатију као практични -доминантно-васпитни идеал јелинско-атинске културе.

Од тренутка када калокагатија као друштвено-васпитни феномен добија велики и снажан трансмисионо-културни значај и утицај, назире се прогресивни развој филозофске а самим тим и педагошке мисли на тлу старог континента. У овом циклично-динамичном периоду формирања друштвено формалне основе калокагатије као и њених васпитно-рефлексивних модела, развија се универзалистичко-хуманистичка основа доктриналног учења о човеку као микро-макро козмичком центру универзума. Такво позиционирање експлоративног јелинског духа са нуклеусним хомоцентричним тежиштем те својом нужном предиспонираном и богатом научно-истраживачком ризницом отвара пут томе да се Грци у античком свету појављују као првобитни мислиоци и научници Европе прохуманистичког карактера (Efland, 1990). Првобитно може се сматрати да фокус њиховог испитивања јесте потрага за знањем (episteme) ради њега самог (Koplston, 1988), при чему се латентно у духу времена обликује и формира оно што се данас у савременом хуманистичком дискурсу подразумева под окриљем научно-слободног и безпредрасудно-испитивачког духа спознаје и сазнања света појавних ствари.

У основи приближнија одредба јелинско-атинског модела васпитања подразумева формирање личности у складу са њеном натуралистичко-хуманоидном природом. Управо у том споју компонентално природног и човечанског, јелински човек својом динамичком рефлексијом у делатној пракси даје форму животности оном скривеном ентелехијском што носи у себи (Đurić, 1976). На јелинској сцени друштвено-делатног збивања васпитни идеал калаокагатија у себи обједињује два пола врлинског живота коме је јелински човек тежио, а 
који су у својој експлицитно-имплицитно садржинској форми изражени у савршеном хармонично-складном оваплоћењу калокагатије. Аксиолошко-садржинска структура васпитног идеала калокагатије нормативно је одређена као етичка, док се самом категоријом изображава бит врлинског живота - бити човек леп и добар. У поларитетним односима лепог и доброг изражених кроз обједињујућу форму калокагатије, реч калос (каגо́ - леп) за старе јелине односио се примарно на физичку лепоту и неизбежну „ауру“ еротицизма која је прати, чиме се изображавала њена експлицитна форма, док реч агатос ( $\alpha \gamma \alpha \theta$ ó $\varsigma$ - добар) сигнифицира морални аспект личности чиме је назначена њена имплицитно-есенцијална форма (Marrou, 1956 : 43-44).

Сам појам добија своју ствароносно аксиолошку глорификацију у филозофској мисли са Платоном, тако се придев kalos употребљавао у нечулном значењу доброг и исправног у смислу добро живети, добро говорити односно имао је прагматичну морално-техничку природност употребе. У том смислу постоји веза са agathon, тако да су Грци за свој идеал племенитости и доброте „сковали“ реч kalokagathia, при чему се не ради о „синонимности двеју категорија већ више о преклапању појма лепог и доброг“ (Guthrie, 2007; prema Grubor, 2010: 97).

Платонова филозофска мисао изложена у форми дијалога наизглед конкретно не открива философски системски изграђен и заокружен какав примера ради налазимо у његова ученика Аристотела. Па ипак, Платон остаје као идејни творац који разрађује и опсежно развија идеалистички метод сагледавања стварности насупрот културолошко-идеолошкој поставци и философском утемељењу релативизма карактеристичним за период процвата паидеје у старој Хелади који се промовише и пропагира од стране софиста (Pavićević, 1967). Јединствена философија софизма афирмише хуманистичко-васпитни модел човека наглашавајући своје основе идеје о унутарњој хармонији - eyритмији. У основи њихова учења истичу се максиме да је „човек мера свега“ и да „васпитање неће процветати у души ако се не дође до велике дубине“ постављајући на тај начин темеље рациионалног хуманизма (Suhodolski, 1970: 11). Насупрот рафинирајућој филозофији софисма и заговора универзалистичкорелативистичке спознаје света, Платонова философска мисао је критички усмерена против експлицитно-философских ставова софиста нарочито у сегменту епистемологије која из чулног опажањ а примарно изводи свеукупну теорију сазнања (Zilioli, 2016). Тако позни Платон софистичкој сентенци Протагоре „човек као мера свих ствари“ супротставља експлицитно изложен став „Бог је понајвише мера свега, а не неки како кажу човек“ (Barbarić, 1995). Овако изложен став има своју дубоку постулацију у учењима питагорејаца које Платон рефлексира кроз своје учење са обележјима орфичких мистерија, религиозног усмерења, бесмртности душе, проповедачке реторике у дијалозима, наклоности ка бројевима и дубоким унутршњим спојем рационалног и мистичног. Односно, то би се могло сагледати de facto да је платонизам у својој суштини питагорејство, као и да се са Питагором ,рађа замисо о једном вечитом свету, који се открива уму али не и чулима““ (Rasel, 1998: 55). 
У сегменту егзистенцијалног и флуидно-комплексивног битисања људског бића у датој реалности, да би његова конкретно дата природна диспозиционарност (људскост као таква) имала својих врлинских обележја (тежњу ка Лепом и Добром), односно могућност развоја и саморазвоја достизања сваке врлине, основна је претпоставка која је садржана у практично-делатној констелацији прикладног васпитања на релацији ка и од свесно-самосвесног субјекта. Другачије речено маниром платонистичке реторике, да је кобна и жалосна судбина и најплеменитијих душа које постају рђаве ако приме рђаво васпитање, при чему се може избећи њена декаденција у конотацији - рђава, и да је предупређење таквог стања могућно ако се људска природа адекватно засади и гаји на плодном тлу, дакле прикладним васпитањем које ће усмеравати васпитаника према врлини (Platon, 2002). Тако ће Платон у свом делу Држава изнети експлицитне ствове који су и у данашњици актуални и важни за разумевање и сагледавање природе проблема хуманистичких позиција васпитног модела човека. О проблему и значају култивације и оплемењивања људског бића посредством доброг (прикладног) односно њему опозитног рђавог васпитања кроз форму дијалога у ликовима Сократа и Глаукона, делотворност рђавог васпитања и његовим последицама по личност васпитаника Платон сагледава овако:

- Мислим да такав човек постаје непријатељ логоса (мисологос) и необразован (амоусос). Будући непријемчив за разлоге, он се понаша као нека дивља звер, свуда примењује силу и грубост, живи у незнању и глупости, иза којих стоје аритмија и неоплемењеност (Platon, 2002: 95).

Са друге, стране уколико васпитаник има адекватне и подстицајне животне услове у којима се развија и расте, односно о добром васпитању Платон казује следеће:

- Васпитање и образовање, ваљано извођени, формираће добре природе; а ове ваљане природе ће, са своје стране, бити у стању да образовањем формирају генерацију још бољу од претходне, у осталом бољу и по рођењу, као што се догађа и код других живих бића (Platon, 2002: 107).

За педагошки дискурс у сегменту хуманистичких позиција, платонистичка мисао има важне импликативне садржинске елементе. За потребе нашег испитивања то се превасходно манифестује у интересном подручју сагледавања процеса култивације и оплемењивања психофизичких структура људског бића. Тако у поларитетно аксиолошко-опозитном односу врлина-pђавост, онтолошко-етичка нужност налаже васпитно-практичној делатности комплексан задатак раста и развоја људске природе, односно a priori структуралну модуларност калокагатије која per se (по себи) изображава телоспонзичност (сврховитост) naидеистичког платонизма те својим топично-базичним тежиштем стоји ка врлини (Доброг и Лепог). Дакле, Платон и његова далекосежно-дубокоумна филозофска мисао интенцира и отвара поља могућих васпитних модела човека која су и у данашњици актуална и важна за разумевање и сагледавање природе проблема хуманистичких позиција субјекта у васпитно-образовној делатности. 
Форма која је дата у претходном излагању садржински представља једну од мноштва могућности сагледавања овакве врсте педагошко-филозофске опсервације од значаја за развој хуманистичког утемељења теорије васпитања. У том смислу, можда је најподесније овај сегмент рада завршити закључном хиптезом платонистичког философисма изложеног у дијалогу о идејама која рефлексира универзалистичку спознајну вредност дате реалности:

- Нека то буде речено, и још ово: било да Једно постоји, или да не постоји, оно и друге ствари, како изгледа, у њиховом односу према себи, и у њиховом узајамном односу, на све начине, јесу све, и нису ништа, и изгледају све, и не изгледају ништа. — То је савршена истина (Platon, 1959: 76).

Конзеквентну позицију status quо сазнања о доброј и лепој васпитнообразовној делатности импликативно видимо у наведеној сентенци. Овакву пригодност привржености Платоновом идеализму налазимо у сфери круцијално важној за спознају истинитости гносеолошко-епистемолошке природе васпитања. Тако, дијалектична сферичност природе испитивања васпитних концептуалних модела (између осталог и хуманистичког) преиницијално и принцепијелно налаже пропитивање проблемске комплексности спознаје чистог дијалектичког сазнања Доброг и Лепог, односно онтолошко-проблемског структурума сазнања (Доброг и Лепог) у реверзибилно-иреверзибилном сазнајном димензионалитету васпитне теорије и праксе.

\section{2. Основни постулати хуманистичко-васпитног концепта у рефлексији (пост)модернистичко-теоријског дискурса - плурализам приступа}

Личност је таква да ће вас увек изненадити Карл Густав Јунг

За испитивање основних постулата матрице хуманистичко-васпитног модела човека важно је истаћи неке појмовне одреднице и недоумице везане за категоријално-садржинско назначење појма хуманизам. Под појмом хуманизм у ширем контексту значења може се подразумевати плурализам идеолошких концептуалности који у средиште свога проматрања поставља људско биће и његове сасвим особене развојне капацитете који га издвајају од осталих живих бића. Таква хомоцентристичка позиција кроз научно-философски вредоносни систем отвара пут решавања сопствених проблема егзистенцијалног карактера те могућност неистражености граница домета људске спознаје (Edwords, 1989; Kurtz, 2000). Према Едвордсу (Edwords, 1989) реч хуманизам изазива конфузију управо због нејасног назначења у контексту у ком је у употреби. Према њему овај проблем је решив употребом одговарајућих придева чиме се јасно назначавају и одвајау субкатегорије хуманизма. За нас је у овом контексту за- 
нимљива субктегоријална врста хуманизма која се означава као филозофски хуманизам. Под њим поменути аутор подразумева било који поглед или начин живота који је усредсређен на људску потребу и интерес. Његова садржинско-структурална одредница у овом смислу највише погодује базичној основи предметног поља испитивања, односно оном сегментима хуманистичковаспитне матрице калокагатије који иманентно указују на личносно-релацијске перманентне процесе развоја и саморазвоја.

Хуманистички мислиоци кроз епохе дубински и опсежно пропитују све сфере и стања човековог постојања, њихова запажања о ономе што јесте односно, о ономе што није истинска људска природа, умногоме илуминише пут ка хуманистичком карактеру разумевања, схватања и формирања људског бића. Хуманистички концепт у васпитању почиње своју јасну транзицију и трансформацију ка обликовању нове парадигме човека и нове философије живота модерног доба у епохи ренесансе и реформације истицањем централне теме хуманизма: неговање и култивисање људских потенцијала у највећој могућој мери (Kallendorf, 2003: 76; Cordasco, 1976). Хуманистичко васпитање је веома тешко позиционирати у оквирма само једног теоријског правца или покрета. Оно налази превасходно корене у скоро свим праксеологијама филозофских и етичких теорија чија је заједничка нит позитивно унапређење људског развоја, достојанства, благостања (Aloni, 2011: 34). Тако су од кључног значаја садржинска уобличавања васпитних форми која у интерактивном односу са васпитаником експлицитно подржавају и негују идеју о себи, могућности креативних и стваралачких способности раста као и развој о свесности партициnaщ̧ије по социјални напредак (Pearson \& Podeschi, 1999).

У савременој теоријско-философској мисли можемо издвојити три правца који својом идеолошко-структуралним основама указују на базичне конструкте хуманистичких индикативних полазишта, а самим тим и могућим исходиштима по хуманистичко-васпитни модел човека. Овде је важно напоменути да ће бити узети у обзир само суштински важни елементи свих поменутих праваца без претензије дубиозније анализе истих.

Први правац на који ћемо се осврнути јесте феноменологија, заједничке упоришне тачке могућих индикативних елементарних структура са хуманистичком филозофијом виђене су у следећим сегментима (Savićević, 1989; Hitt, 1969):

- наглашена перцепција личности која се развија на основу искуства;

- човекова суштина је унутар њега самог;

- људско биће јесте извориште свога делања;

- у свакој ситуацији људско биће има могућност слободног избора;

- човека је могуће описати терминима који се односе на његову свест;

- холистички приступ изучавању људских особина;

- човек живи у субјективном свету;

- људско биће има одлике ирационалног бића;

- човек производи информације и увек је више од граница својих сопствених спознаја; 
Следећи правац на који ћемо се осврнути јесте егзистенцијализам, његови упоришни и потенцијално заједнички структурално-садржински елементи могу се сагледати у следећим сегментима (Mitrović, 1976: 372-384):

- одговорност индивидуе да постане управо оно што жели;

- посредством избора човек ствара своју личност;

- прилика човека да слободом и избором који има постане човеком;

- наглашавање дијалектичке и активизирајућу природе људског бића;

- одсуство било којих форми присиљавања у практичном делању индивидуе;

- придавање веће пажње и значаја афективној страни људске личности;

- развој естетских и моралних осећања;

- примарну улогу у формирању личнсти имају процеси самосазнавања;

- идеје љубави и слободе су водиље људског бића.

Трећи правац на који се у највећој мери ослања хуманистичка педагогија је хуманистичка психологија како нас упућује Ђорђевић (2012), у складу с тиме осврнућемо се на основне детерминанте таквог становишта приказом дуалне схеме која ће нам репрезентативно указати на постулате хуманистичког структурално-садржинског поља (Поповић, 2002):

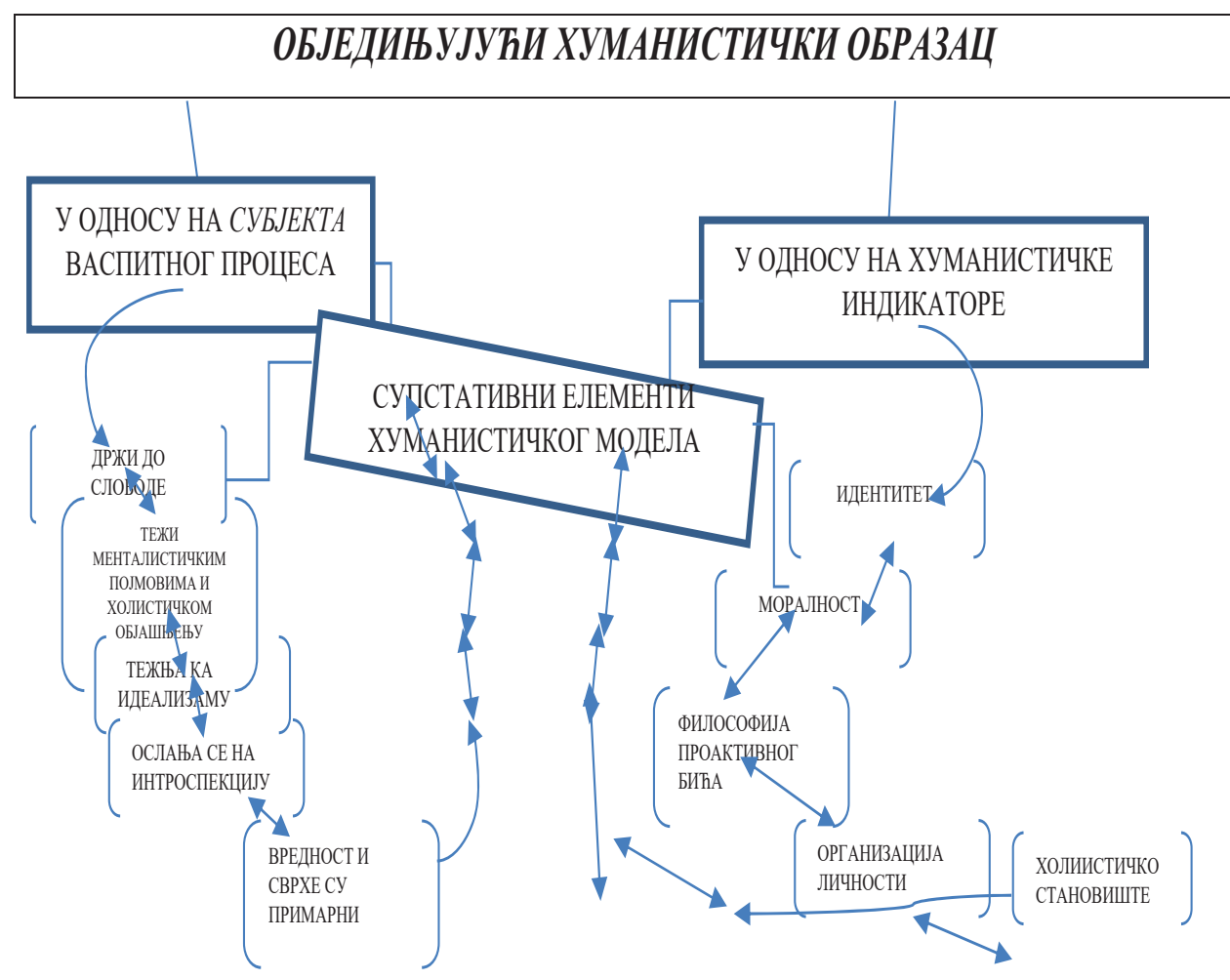

Слика 1: Дуална схема обједињујућег хуманистичког обрасца 


\section{3. Теоријске (не)могућности у контексту комплементарног односа јелинско - постмодернистичке философије васпитања}

Људи путују па се диве висовима планина, дивовским валовима мора, дугим токовима река, широким пространству океана, и кружном покрету звезда; а поред себе пролазе и - не чуде се ничем.

Свети Августин

У перспективи могућности сагледавања јединствености васпитног мо-

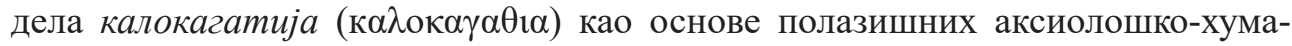
нистичких вредности васпитног модела човека, преиницијално, осврнућемо се на сегмент немогућности односно индикативно отежавајућих структуралних елемената који указују на непостојаност, односно могућу неодрживост јединствености интеграције компаративних модуларности, те њихову могућу одрживост јединствености интеграције компаративних модуларности. Као што је наведано у претходним поглављима категорија калокагатије иманентно своју културолошко-друштвену актуализацију добија у филозофским структурумима јелинске мисли. Сама временска разлика настанка одређених филозофских структурума који актуализују у културолошко-друштвеној реалности категорију калокагатије као егзистенцијално-идеалистички пожељан модел битисања људског бића, дакле бити човек добар и леп, осатављају пред нама несагледиву временску разлику (две хиљаде петстотина година) у домену реалних и објективних могућности сагледавања природности генезе развоја у свом временском току. Временска разлика као таква у себи носи сасвим особене модуларности једне одређене културолошко-друштвене реалности које у складу са потребама и интересима одређеног културолошко-друштвеног поретка потенцира и актуализира аксиолошку номенклатуру као инстанције ка којима је потребно усклађивати друштвено-индивидуалну егзистенцијалност. Дакле, културолошко-друштвене околности и услови настанка идеолошког феномена калокагатије у периоду паидеје партикулирају као такви једну сасвим одређену хуманистичко-васпитну матрицу коју је тешко и готово немогуће сагледати у перспективи савременог тока актуталног цивилизацијког временско-просторног збивања. У савременом контексту када говоримо о самој категорији калокагатије можемо говорити о њеним рафинираним и преегзистенцијалним формама хуманистичко-васпитне матричне модуларности с обзиром да нам се њена примарна топика природности спознаје као такве превасходно манифестује кроз сачувано литерарно стваралаштво старојелинских философских мислилаца. Код савремене концептуалне тенденције у хуманистичком поимању васпитно-матричног модела латентно се могу препознати рециидви паидеистичког васпитног модела и то у оном сегменту који бисмо могли сматрати заједничком додирном тачком, односно у есенцијалним питањима о људском бићу као актеру и делатнику сасвим одређене и конкретно дате временско-просторне макро и микро егзистенцијалне перспективе. Оваква до- 
дирна тачка је могућа посредством онога што можемо категорисати као атемпорална константност која се односи на ванвременску актуалност природе пропитивања филозофских структурума дате појавне феноменолошке реалности чији је главни актер и иницијатор структуре пропитивања опет људско биће. Дакле, атемпорална константност отвара пут премошћавања егизистенцијалног темпоралног вакуума једне микро-макро козмичке перспективе позицонирајући људско биће као примарно језгро (prima nucleus) аксиолошког димензионирања хуманистичко-васпитне матричне модуларности.

Коначно, у завршници поглавља сагледавамо могуће индикативне елементе као спој односа компаративног модуларитета јелинско-постмодернистичке васпитне филозофије кроз њихове сличности и разлике рефлекирајући у нацрту могућу базичну основу хуманистичко-васпитне матрице калокагатије:

Табела 1. Приказ компаративног модуларитета јелинско - постмодернистичке васпитне философије

КОМПАРАТИВНИ МОДУЛАРИТЕТ ЈЕЛИНСКО - ПОСТМОДЕРНИСТИЧКЕ ВАСПИТНЕ ФИЛОСОФИЈЕ

МОГУЋИ ИНДИКАТИВНИ ЕЛЕМЕНТИ

\begin{tabular}{|c|c|}
\hline & $\mathrm{CE}$ \\
\hline 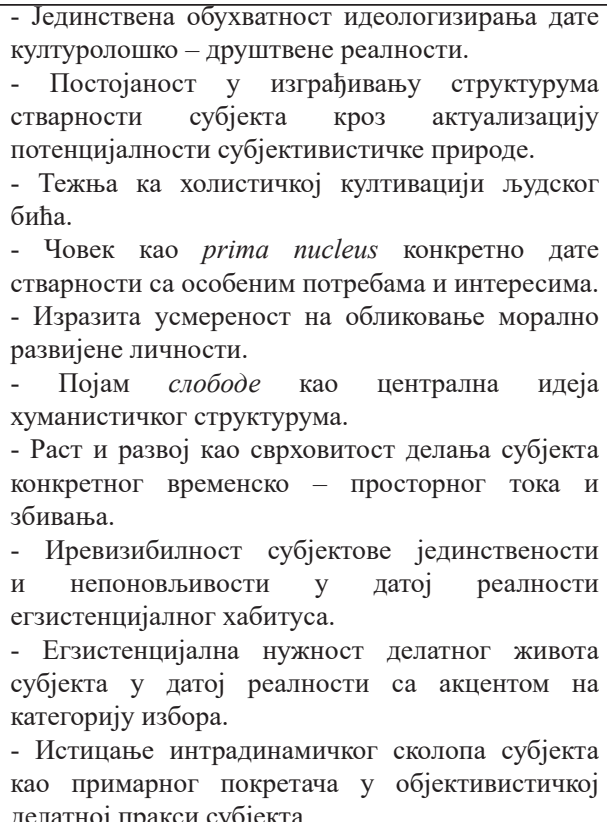 & $\begin{array}{l}\text { - Садржински смисао идеологизиране културолошко } \\
\text { - друштвене реалности. } \\
\text { - Субјективистички сегмент аксиолошког } \\
\text { структурума. } \\
\text { - Холистичка култивација субјекта детерминисана } \\
\text { увремењеним околностима и ситуацијама. } \\
\text { - Потребе и интереси сагледани у различитим } \\
\text { димензионалитетима егзистенцијалне реалности. } \\
\text { - Придавање важности у сегменту естетска } \\
\text { васппитања, постмодернисти секундарно } \\
\text { наглашавају важност истог, док код јелина има } \\
\text { примарност као и морални васпитни опсег. } \\
\text { - Поимање појма слободе у односу на полазне } \\
\text { поставке философско - онтолошке структуре } \\
\text { сазнања. } \\
\text { - Различито тумачење у садржинском сегменту } \\
\text { категорија јединствености и непоновљивости. } \\
\text { - Ваљаност избора делатног живота појединца } \\
\text { у смислу афирмативно - аспирационих схема } \\
\text { метациљева. } \\
\text { - Различитост у примарности придавању делатне } \\
\text { снаге одређеним склоповима интрадинамичког } \\
\text { карактера субјекта (интелектуална, емоционална, } \\
\text { вољна...) }\end{array}$ \\
\hline
\end{tabular}




\section{Закључна разматрања}

У сфери могућег споја савремених и античких филозофских структурума савремени хуманистички интерес за античку калокагатију би се сагледао у сфери аксиолошке атрибуције оних аксиолошких номенклатура које у процесу васпитања субјекту отварају могућност ка путу истинског развојног и саморазвојног процеса. Овде смо на позицији да субјектов пут спознаје добра и лепа као такви носе по себи одлике атемпоралне константности те да уз одговарајућу сврсисходност и целисходност васпитног процеса можемо говорити не само у потенцијалу и могућности о добром и лепом васпитанику, већ о актеру васпитно-образовног процеса који то јесте. Такав захтев по нужношћу саме природе итендира комплексно-мултидимнзионално истраживачко поље педагошких феномена који би се морали одредити сасвим конкретније у сфери аксиолошке атрибуичие оних номенклатура које су примарне као постојани модус тежње ка добром и лепом у педагошкој теорији и пракси. С обзиром на категорију васпитања која у својој генези још увек јесте она која је у свом настајању као хиперрефлексивна продукција спознајних аксиолошких, методолошких, епистемолошко-гносеолошких продуката предметно одређене структуре истраживачког поља педагошке науке, хуманистички образац као њен субконститутивни елемент јесте онај који у бити свог конгломератског актуализујућег спектра феноменолошке појавности може и мора бити примарни предуслов каузалистичке консеквентности праксе субјекта. У прилог томе овде нам може послужити аналогија са културно-историјском теоријом Виготског, по којој су менталне функције предетерминисане у свери социјалног, историјског и културног. Култура као таква јесте универзални образац развоја појединаца због вишедимензионалног садржаја културних артефаката. Даље, појединац те културне артефакте (продукти индивидуалне и колективне делатности човека) интериоризује и уграђује у сопствене унутарње структуре које чине основу сваке више форме понашања (Vigotski, 1977). Дакле, водећи се оваквом аналогијом сам субјект васпитно-образовног процеса уколико претпоставимо његову синкретичку структуираност (ка добром и лепом) има потенцијалних могућности за актуализацију оних сфера његових снага на ону датост у реалности у којој препознаје своје потребе и инетресе. Преиницијално, то би значило да на самом васпитном старту васпитно-образовна делатност има понудити у том смислу целисходно и сврсисходно подстицајно-развојно вођење субјекта васпитног процеса као утицајност деловања на целовиту психофизичку структуру. Постојаност оваква приницијална стања би се могла сагледати све до стања активизације преласка од модела утицаја на развој до модела саморазвојне достотности, када субјект својом психофизичком зрелошћу преузима истинску одговорност за даље сопствено развојно-делатно подручје у свим сферама живота. 


\section{Литература}

Aloni, N. (2011). Humanistic education: from theory to practice. In W. Veugelers (Eds.), Education and humanism: Linking autonomy and humanity (pp.35-46). Rotterdam: Sense Publishers.

Barbarić, D. (1995). Grčka filozofija. Zagreb: Školska knjiga.

Collingwood, R. G. (1994). The idea of history. Oxford: Oxford University Press on Demand.

Cordasco, F. (1976). A brief history of education: a handbook of information on Greek, Roman, medieval, Renaissance, and modern educational practice. New York: Rowman \& Littlefield.

Đurić, M. (1976). Istorija helenske etike. Beograd: BIGZ

Ђорђевић, J. (2012). Хуманистичка педагогија. Годишњак Српске академије образовања, Година осма. (стр. 435-438). Београд: Српска акдемија образовања.

Efland, A. D. (1990). A history of art education. New York: Teachers College Press.

Edwords, F. (1989). What is humanism. Phoenix: Johnson Consulting Network (JCN).

Guthrie, W. K. C. (1962). A History of Greek Philosophy: Volume 2, The Presocratic Tradition from Parmenides to Democritus. London: Cambridge University Press.

Grubor, N. (2010). Platonova estetika lepog. Arhe, 7(13), 1- 25.

Hitt, W. D. (1969). Two models of man. American Psychologist, 24(7), 651-658.

Koplston, F. (1988). Istorija filozofije, tom I: Grčka i Rim. Beograd: BIGZ.

Kallendorf, C. (2003). Humanism. In R. Curren (Eds.), A Companion to the Philosophy of Education (pp.62-72). Malden: Blackwell Publishing.

Kurtz, P. (2000). Humanist manifesto 2000: A call for a new planetary humanism. New York: Prometheus Books.

Mills, J. (2002). A pedagogy of becoming. Amsterdam: Rodopi.

Mitrović, D. (1976). Moderni tokovi komparativne pedagogije. Sarajevo: Svijetlost.

Marrou, H. I. (1956). A history of education in antiquity. New York: Sheed and Ward.

Pearson, E. M., \& Podeschi, R. L. (1999). Humanism and individualism: Maslow and his critics. Adult Education Quarterly, 50(1), 41-55.

Pavićević, V. (1967). Osnovi etike. Beograd: Kultura.

Popović, B.V. (2002) . Bukvar teorije ličnosti. Beograd: Centar za primenjenu psihologiju.

Platon, (2002). Država. Beograd: BIGZ.

Platon, (1959). Parmenid. Beograd: Kultura.

Rasel, B. (1998). Istorija zapadne filozofije i njena povezanost sa političkim i društvenim uslovima od najranijeg doba do danas. Beograd: Narodna knjiga - Alfa.

Suhodolski, B. (1970). Tri pedagogije. Beograd: NIP - Duga.

Savićević, D. M. (1989). Koncepcija obrazovnih potreba u andragogiji. Beograd: Zavod za udžbenike i nastavna sredstva.

Vigotski, L.S.(1977). Mišljenje i govor. Beograd: Nolit.

Zilioli, U. (2016). Protagoras and the challenge of Relativism: Plato's subtlest enemy. London: Routledge.

Zeller, E. (2014). Outlines of the history of Greek philosophy. London: Routledge. 


\title{
HUMANISTIC - EDUCATIONAL CONCEPT OF HUMAN: ABOUT THE (IM)POSSIBLE COMPLEMENTARY RELATIONSHIP OF THE HELLENIC AND CONTEMPORARY PHILOSOPHY OF EDUCATION
}

\author{
Milan Miljković \\ University of Niš, Faculty of Philosophy, Department of Pedagogy \\ (PhD student)
}

\begin{abstract}
The undeniable fact is that the Hellenic philosophical idea has universal and original products of human knowledge in all fields of research in the phenomenal sense. In this study on the theoretical way is selectively represented the Hellenic philosophy thought in the spirit of the paidea $(\pi \alpha 1 \delta \varepsilon i \alpha)$, as well as the posmodernistic humanistic thought in the segment of the philosophy of education. As a premise of this research it is analyzed relationship between comparative modalities of the Hellenic - postmodernist educational philosophy and (in) possibility of perceiving their complementary relationship in the segment of the integration of the unique theoretical model of the humanistic - educational matrix. The category of kalokagatia $(k \alpha \lambda \circ \kappa \alpha \gamma \alpha \theta i \alpha)$ as a unique and universal phylosophical and pedagogical product of Hellenic culture is considered as the central segment of the subject structure of the research field. The purpose of this research are directed towards the analytical examination of the possibilities of positioning the humanistic - educational matrix of kalokagatia $(k \alpha \lambda \circ \kappa \alpha \gamma \alpha \theta 1 \alpha)$ within the framework of comparative modularities of the Hellenic - postmodernist educational philosophy. Furtermore are considered basic theoretical settings of kalokagatia as an expression of the humanistic - educational topology of the Hellenic spirit within is gave a review of Platon 's perception in the segment of cultivation and refinement of human nature. Different theoretical considerations of the postmodern - humanistic orientation are analyzed in the segment of hierarchical integration of basic categories which are important for educational matrix of kalokagatia. The results of comparative analysis shows that the basic point of humanistic - educational matrix kalokagatia $(k \alpha \lambda о \kappa \alpha \gamma \alpha \theta i \alpha)$ receives its operational connotation of intermediaries between the Hellenic and postmodern educational philosophy.
\end{abstract}

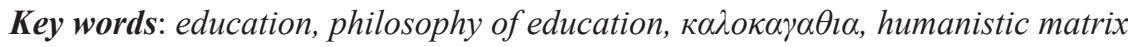

\section{Citiranje članka:}

Miljković, M. (2019). Humanističko - vaspitni koncept čoveka: o (ne)mogućem komplementarnom odnosu jelinske i savremene filosofije vaspitanja. Godišnjak za pedagogiju, 4(1), 101-114 